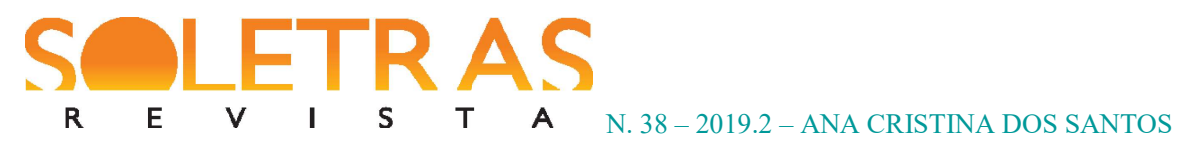

\title{
Sujeitos femininos desenraizados ou as novas experiências do não pertencimento
}

\author{
Ana Cristina dos Santos ${ }^{1}$
}

\begin{abstract}
Resumo: Este trabalho discute as novas relações com o espaço que resultam das experiências dos deslocamentos e suas consequências para as personagens femininas que configuram a chamada segunda geração do exílio - filhos de pais exilados das ditaduras latino-americanas. Tem também como objetivo verificar de que maneira a perda dos referentes espaciais modificam esses sujeitos femininos desenraizados. Para tanto, analisam-se as personagens femininas principais dos romances Apenas diez (2006), da escritora uruguaia Marisa Silva Schultze e Pasajeros em tránsito (2013), da escritora chilena Rossana Dresdner. Verifica-se que os romances problematizam o contínuo "estar em trânsito" das personagens e suas ambiguidades culturais que permitem, com base nas experiências do deslocamento, a construção de uma subjetividade nômade produtora de sujeitos híbridos e traduzidos. Para a análise proposta, utilizam-se os textos de Norandi (2015) e Espina Bocic; Sanhueza Comte (2014) sobre a segunda geração do exílio; de Brah (2011) e García Canclini (2009) para as noções de espaço e deslocamento; de Said (2003) para as questões de exílio; Benedetti (1983) para o conceito de desexílio e Hall (2005) e Braidotti (2002) para as questões das identidades na contemporaneidade.
\end{abstract}

Palavras-chave: Deslocamento. Escrita de autoria feminina. Exílio. Subjetividade nômade.

À medida que viaja, o viajante se desenraíza, solta, liberta [...]Tanto se perde como se encontra, ao se tempo que se reafirma e modifica. No curso da viagem há sempre alguma transfiguração, de tal modo que aquele que parte não é nunca o mesmo que regressa. (IANNI, 2003, p. 31)

\section{Introdução}

A viagem e o exílio sempre estiveram presentes na literatura latino-americana como temas constantes e permanentes entre os escritores. ${ }^{2} \mathrm{O}$ tema da viagem mistura-se com o da própria descoberta da região e tornou-se assunto literário tanto de escritores que vivem nesse território quanto dos que vivem, por força das circunstâncias ou por vontade própria, fora dele. O tópico do exílio foi sendo incorporado, pouco a pouco, à região à medida que os escritores se exilavam e intensificou-se a partir de 1970, quando vários escritores saíram de

\footnotetext{
${ }^{1}$ Doutora em Letras Neolatinas pela Universidade Federal do Rio de Janeiro. Atua como professora associada de Literaturas Hispânicas na Universidade Federal do Rio de Janeiro, professora do Programa de Pós-Graduação em Letras (UERJ), membro do GT Vertentes do Insólito Ficcional (ANPOLL). Rio de Janeiro, Brasil. E-mail: anacrissuerj@gmail.com (i) https://orcid.org/0000-0002-5232-6825

${ }^{22}$ Para o crítico literário Emir Rodríguez Monegal (1982, p. 45) o tema da Literatura latino-americana na segunda metade do século XX era o exílio e essa literatura foi escrita, quase sempre, por escritores exilados.
} 


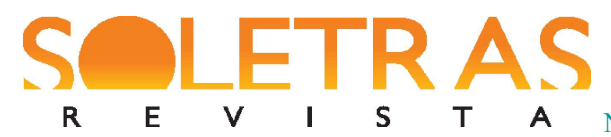

N. 38 - 2019.2 - ANA CRISTINA DOS SANTOS

seus países, por escolha ou por imposição, deixando para trás os regimes ditatoriais, principalmente os dos países do Cone Sul: Argentina, Uruguai, Paraguai, Brasil e Chile. A situação de exílio desses escritores motivou a criação de romances, ensaios, e revistas que discutiam, sempre com alguma dor e nostalgia, o sentimento de perda da terra natal. De tal forma que não é contraditório afirmar que o tema do deslocamento e da mobilidade espacial já se encontrava estabelecido nesses países quando, nas últimas décadas do século XX e no século XXI, tornou-se tópico constante nos estudos literários e culturais contemporâneos. Assim, a tendência de abordar o tema do deslocamento na literatura latino-americana do século XXI dialoga com essa tradição da movimentação das personagens por meio da viagem e do exílio já enraizada na produção literária da região.

Ainda que haja uma tradição do tema na literatura latino-americana, as reflexões sobre a experiência do deslocamento na contemporaneidade trazem marcas que se diferenciam das realizadas em momentos anteriores. Antes, as narrativas de deslocamentos abordavam, em sua maioria, o exílio e o sentimento de nostalgia e de perda das personagens ao deixar o seu país de origem. As personagens dos romances mantinham o laço afetivo com o seu lugar natal. $\mathrm{O}$ território estrangeiro era experimentado como um lugar provisório, de passagem, pois o desejo final era o de retornar ao lugar de origem. Os sentimentos das personagens refletiam os de seus escritores que, como nos assevera Said (2003, p. 50) ao analisar as narrativas de escritores exilados, sentiam “... o exílio [como] uma solução vivida fora do grupo: a privação sentida por não estar com os outros na habitação descomunal [já que] os exilados estão separados das raízes, da terra natal, do passado".

O escritor, ao abandonar o país em uma situação de exílio, cultivava um sentimento de ausência, de dor e, por tal motivo, mantinha em seus textos uma relação nostálgica com o espaço nacional e cultivava neles a sua identidade nacional e cultural, valorizando a sua terra natal. Suas narrativas refletiam a temática da perda e da despossessão identitária que sentiam ao viverem no estrangeiro. Por tal motivo, suas personagens enfatizavam o pertencimento à nação e à cultura de origem, mantendo-se, assim, vinculados a uma identidade única, relacionada à terra natal. Essa narrativa e seus escritores, presentes na literatura latinoamericana até as primeiras décadas da metade do século $\mathrm{XX}$, são conhecidos como pertencentes à primeira geração do exílio.

Já os escritores deslocados da última década do século $\mathrm{XX}$ e dessas duas primeiras décadas o século XXI, que enfocam a mobilidade contemporânea, rompem com o sentimento 


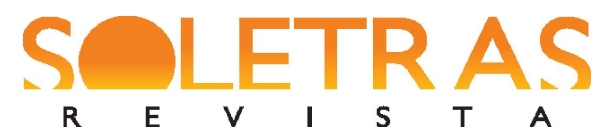

N. 38 - 2019.2 - ANA CRISTINA DOS SANTOS

de nostalgia que a primeira geração possuía com o país de origem. Em suas narrativas, suas personagens ultrapassam as fronteiras de seus países e, a partir desse espaço "estrangeiro", mesclam a cultura do país de origem com a do país de chegada. São personagens que, tais quais seus escritores, não abandonam completamente a relação com o país de origem, mas reconfiguram o sentimento de pertença, construindo um jogo identitário múltiplo, cujo sentimento de pertencimento abarca as duas culturas: a do país natal e a do país de chegada.

Em suas narrativas discutem as experiências do deslocamento pelos espaços urbanos contemporâneos e abordam o "transitar entre dois mundos" - tais como eles próprios fazem. Muitos desses romances ainda centram suas narrativas nos países de origem do escritor, mas refletem sobre o trânsito, o desenraizamento, a reterritorialização, a errância, o hibridismo cultural e o nomadismo. Enfim, os escritores contemporâneos que abordam a viagem e o exílio estabelecem diálogos entre o aqui e o lá e ressaltam a impossibilidade de representarem uma única identidade e de manterem o pertencimento a um único grupo. Suas personagens reproduzem identidades plurais, híbridas e traduzidas ${ }^{3}$, tais quais as deles próprios.

Entre esses escritores contemporâneos que abordam os temas da viagem e do exílio, surge, a partir da primeira década do século XXI, um grupo específico: os filhos dos exilados das ditaduras hispano-americanas, que viveram no estrangeiro com os pais e que começaram a publicar romances sobre a experiência do exílio e o viver entre dois mundos.

São escritores que saíram do país natal ainda crianças, acompanhando os pais no exílio, e viveram no país de chegada. Como consequência, cresceram fora de seus países e conviveram com/entre duas ou mais culturas. Eles são conhecidos pela crítica literária hispano-americana como a segunda geração do exílio ${ }^{4}$ e publicam seus textos em língua espanhola, a língua do país de origem. Alguns voltaram com os pais, quando esses retornaram ao país de origem e passaram a viver ali, mas mantêm um constante ir e vir entre os dois países - o de partida e o de chegada. Outros permaneceram nos países em que cresceram e

\footnotetext{
${ }^{3}$ Conforme o conceito de "Tradução", de Stuart Hall (2005, p. 87-9).

${ }^{4}$ Nesse trabalho, se utiliza o conceito de "segunda geração do exílio" conforme o definido por Mariana Norandi (2015, p. 54. Grifo meu) para os países do Cone Sul: "[...] al llegar a los estudios sobre "segunda generación" y "víctimas de las dictaduras del Cono Sur" el uso de esta categoría ha sufrido modificaciones y alude a aquellos niños y jóvenes - hoy adultos- cuyos padres fueron afectados por la represión política de aquellos regímenes y que nacieron antes, durante o después del periodo dictatorial. Por lo que "segunda generación", vinculada a la categoría de víctimas de la dictadura, incluye a los hijos de desaparecidos, asesinados, clandestinos, presos políticos y exiliados. Dentro del mismo contexto histórico, en el caso particular de la "segunda generación" y "el exilio" esta categoría ha ido adquiriendo cada vez mayor solidez para referirse a los descendientes directos de los exiliados. Es decir, para nombrar a aquellos hijos nacidos antes, durante o después del exilio de sus padres"
} 
escolheram o não retorno ${ }^{5}$ ao país natal. Em seus romances, como nos romances da primeira geração do exílio, o tema da ditadura é o elemento que reestrutura a vida das personagens. Outra característica que aproxima as duas gerações é a presença da segunda geração do exílio, na literatura hispano-americana contemporânea, não só como tema, mas também como autoria.

Com o foco na segunda geração do exílio como tema e autoria, este trabalho discute as novas relações com o espaço que resultam das experiências dos deslocamentos e suas consequências para as personagens femininas que configuram a chamada segunda geração do exílio na literatura hispano-americana. Objetiva também verificar de que maneira a perda dos referentes espaciais modificam esses sujeitos femininos desenraizados. A análise se centra nas duas personagens femininas principais dos romances Apenas diez (2006), da escritora uruguaia Marisa Silva Schultze e Pasajeros en tránsito (2013), da escritora chilena Rossana Dresdner.

\section{O não pertencimento da segunda geração do exílio}

Os romances da segunda geração do exílio discutem o exílio, e o desexílio ${ }^{6}$, a questão do pertencimento e a reconstrução identitária das personagens, pois essas, assim como os autores, estão atravessadas por duas ou mais culturas. Os escritores pertencentes à segunda geração são sujeitos desterritorializados, fraturados, que chegaram crianças ou adolescentes no país do exílio e lá cresceram e construíram a sua subjetividade a partir da experiência de pertencer e transitar entre as culturas dos dois países. Por tal motivo, essa geração é portadora de uma condição singular: o hibridismo cultural ${ }^{7}$. São de lá (o país do exílio), mas também daqui (o país natal), aprenderam a "negociar com as novas culturas em que vivem, sem simplesmente serem assimiladas por elas e sem perder completamente suas identidades"

\footnotetext{
5 Sobre o termo "não retorno", Norandi (2015, p. 55) explica que "[...] el no retorno representa no volver a establecer la residencia permanente en el país de origen tras una experiencia de exilio, aun cuando las circunstancias que provocaron esta migración forzada hayan desaparecido".

${ }^{6} \mathrm{O}$ conceito de desexílio, termo acunhado pelo escritor uruguaio Mario Benedetti, no artigo intitulado "El desexilio" (1983), designou o árduo processo de volta dos exilados dos países do Cone Sul à terra natal depois de um período de exílio e no qual (re)apareciam sentimentos de nostalgia do país de chegada tão dolorosos quanto os da perda da terra natal no período do exílio.

${ }^{7}$ Utilizamos o termo hibridismo cultural segundo a definição de García Canclini (2008, p. xix): “[...] entendo por hibridação processos socioculturais nos quais estruturas ou práticas discretas; que existiam de forma separada, se combinam para gerar novas estruturas, objetos e práticas".
} 


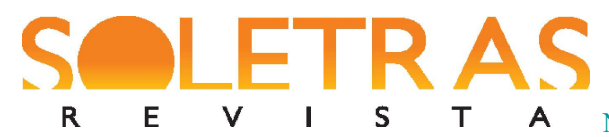

(HALL, 2005, p. 88). Tornaram-se sujeitos conscientes da condição híbrida que possuem e, como tal, manifestam em seus romances o privilégio de viver entre dois mundos e duas culturas por meio de personagens possuidoras de identidades móveis, traduzidas que se definem a partir de sua condição de sujeito errante. Personagens que não conseguem se encontrar nem no país de origem, nem no de chegada, pois, tais quais os autores não possuem uma referência para o termo "estar em casa". O que significa "estar em casa" quando se deve "aprender a habitar, no mínimo, duas identidades, a falar duas linguagens culturais, a traduzir e negociar entre elas" (HALL, 2005, p. 89)?

Por tal motivo, as narrativas da segunda geração do exílio se centram nas consequências do processo de chegada ao país de exílio, na adaptação à nova cultura sem a perda da língua e da cultura do país natal e no desexílio que traz a angústia da volta e muitas vezes a não adaptação, pois, tanto o exilado quanto o país são “outros". O foco está na problematização da questão do pertencimento e seus desdobramentos para a reconstrução identitária das personagens. O tema da ditadura - motivo do exílio - também está presente nos romances, mas aparece como pano de fundo, não é o eixo principal da narrativa, como era para a primeira geração do exílio. Contudo, ainda que o tema perpasse pelos romances, ele é elemento detonador do encontro das personagens com as outras culturas. De modo que a trajetória das personagens não está determinada pela ditadura, mas pela consequência que o deslocamento, causado por essa ditadura, acarretou em suas vidas.

Os romances da segunda geração começam a ser publicados na América Hispânica a partir da primeira década do século XXI e se fazem mais presentes nos países de língua espanhola pertencentes ao chamado Cone Sul da América Latina, onde os regimes ditatoriais foram mais violentos: Argentina, Uruguai e Chile. Duas escritoras se destacam: a chilena Rossana Dresdner e a uruguaia Marisa Silva Schultze, exiladas com suas famílias na Suécia, ainda crianças. As autoras são pouco conhecidas no cenário literário brasileiro. Nenhuma de suas obras foi traduzida ainda para a língua portuguesa e são raros os estudos acadêmicos sobre a produção literária dessas autoras no Brasil. Nos romances das autoras que analisamos nesse trabalho aparece a segunda geração de exilados como tema e como autoria. Vale ressaltar que somente Rossana Dresdner vive atualmente em seu país natal, o Chile. Maria Silva Schultze vive na Suécia até hoje, mas constantemente visita o país natal. A Suécia, país para o qual as autoras emigraram, é também o país para onde se exilam as famílias das personagens principais dos dois romances que ora analisamos. 
O romance Pasajeros en tránsito (2012), de Rossana Dresdner, foi o primeiro romance chileno a retratar ficcionalmente a segunda geração e as consequências do deslocamento provocado pelo exílio e desexílio na vida das personagens. No Uruguai, o tema aparece seis anos antes com a publicação do romance Apenas diez (2006), de Marisa Silva Schultze. Ambos os romances, por meio da história das personagens principais Gabriela e Andrea, respectivamente, problematizam a perda da terra natal, os encontros e os desencontros culturais, a busca pela identidade e a questão de pertencer simultaneamente a dois lugares, duas línguas e duas culturas; enfim, relatam o que foi o exílio, o desexílio e suas consequências para a segunda geração de exilados chilenos e uruguaios.

Nos dois romances, as ações se centram no desexílio e, consequentemente, na reconstrução identitária das personagens Andrea e Gabriela, que migraram ainda na infância e na adolescência, respectivamente, para a Suécia. Contudo, as narrativas ainda retratam as consequências do exílio e do desexílio também para os pais das personagens principais, pertencentes à primeira geração do exílio, que sempre desejaram o retorno ao país de origem, contrastando-a com a segunda geração, que não se importa em continuar no país de chegada, pois já perderam suas raízes com o país de origem. Os romances apresentam as personagens já adultas e em seus países de origem e, por meio de idas e vindas das narrativas, Gabriela e Andrea e as demais personagens rememoram o passado no país de chegada e o retorno ao país natal.

No romance Pasajeros en tránsito, o cerne da narrativa é a personagem Gabriela: o exílio da sua família, sua volta ao Chile, as dificuldades do desexílio e o sentimento de não pertencimento ao país natal e o seu retorno à Suécia. Na obra se intercalam a voz narrativa de Gabriela com as das outras personagens que são as protagonistas dos acontecimentos relatados em um período que vai de 1975 a 1996. Já o romance Apenas diez, trata das consequências advindas do exílio e do desexílio na vida de dez pessoas de uma mesma família uruguaia (os apenas dez do título).

O eixo da narrativa em Apenas diez é a personagem Andrea, pertencente à segunda geração do exílio. Ela é uma jovem uruguaia que, com três anos de idade, partiu para encontrar e viver com a mãe exilada na Suécia. Com a abertura política do país, anos mais tarde, a mãe e o padrasto pertencentes à primeira geração de exilados e que sempre desejaram voltar a viver no Uruguai, decidem voltar com o filho, nascido na Suécia, para o país de origem. Andrea, entretanto, decide permanecer na Suécia. Dois anos após a partida da família 
e, após muita insistência da mãe, ela visita a família na terra natal, o Uruguai, do qual nada recorda. Por intermédio das histórias e das memórias das personagens Andrea, sua mãe Irene e sua avó Lil, entrelaçadas no romance com as dos demais membros da família, são narrados os processos de exílio e de desexílio dos membros da família.

Em ambos os romances, os capítulos não possuem uma ordem cronológica, são narrados conforme a memória das protagonistas: vão do presente ao passado e voltam para o presente, formando um caleidoscópio de vozes e datas descontínuas, formando um quebracabeça que será montado, pouco a pouco, pelo leitor. O espaço das narrativas é a Suécia e o país de origem de cada protagonista, o Chile, de Gabriela e o Uruguai, de Andrea. Os romances iniciam e terminam com as personagens principais em deslocamento. Em Pasajeros en tránsito, a narrativa inicia com Gabriela em um avião, chegando à Suécia, após anos vivendo no Chile, para apaziguar a nostalgia que sentia de sua vida na Suécia, e termina com ela ali, pensando em retornar ao Chile, mas com a intenção depois de voltar constantemente à Suécia. Já em Apenas diez, a narrativa inicia com a chegada de Andrea ao aeroporto do Uruguai e termina no mesmo local, após um mês, com o seu retorno à Suécia e sem qualquer perspectiva de volta ao Uruguai.

O tempo é marcado pelas recordações das personagens que fragmentam o tempo da narrativa. Em Pasajeros en tránsito, desde o início, o tempo se mostra não linear. O tempo nas obras se divide entre presente e passado: a vida das personagens antes do exílio; durante o exílio, na Suécia e; no desexílio. Os romances possuem uma sequência interna que está marcada pela memória dos acontecimentos da ditadura ou dos deslocamentos que cada personagem traz à tona. Cada história vai entrelaçando-se com as outras histórias contadas, até completar as lacunas existentes na história de cada um. Cabe ao leitor ir montando o quebra-cabeça que se forma a partir da memória individual de cada personagem para poder dar sentidos aos fatos narrados, aos deslocamentos e à memória coletiva do exílio e do desexílio para, assim, compreender o que aconteceu com cada um antes e depois da ditadura chilena e uruguaia.

Ambos os romances retratam uma situação comum no desexílio: a fragmentação familiar. Com a abertura política dos países do Cone Sul, os exilados puderam retornar aos países de origem, mas muitos jovens da segunda geração decidiram não voltar ao país natal, uma vez que já estavam adaptados ao país de chegada. Para Espina Bocic e Sanhueza Comte (2014, p. 91), esse fato foi o mais desintegrador da ditadura, pois se o exílio foi familiar, o 
desexílio não o foi. Vários integrantes das famílias exiladas não quiseram voltar e decidiram continuar vivendo no país que os acolheu. Nos romances, essa desintegração familiar acontece com as famílias de Gabriela e de Andrea. A mãe e o irmão de Gabriela decidem voltar para o Chile com a abertura política, mas o pai e ela decidem ficar na Suécia, somente anos mais tarde, ela decide voltar à terra natal. No romance Apenas diez, Andrea também não retorna com a família ao término da ditadura uruguaia e decide viver na Suécia ou em qualquer outro país europeu em que possa estudar e tocar violino. Mães e filhas, nos romances, se separam no desexílio.

Essa é uma das diferenças básicas entre a primeira e a segunda geração retratada nos dois romances: todas as personagens da primeira geração do exílio, os pais, veem a sua vida no estrangeiro apenas como um interstício para a volta à terra natal, e empenham-se em manter a sua língua, a sua cultura e a sua identidade nacional, porque é no país de origem que está a sua raiz, o seu pertencimento. Evitam criar laços no país de chegada, porque estão sempre desejosos de retornar aos seus países de origem. As personagens da segunda geração, os filhos, não cultivam esses sentimentos. Não se preocupam em manter os laços que os unem à terra natal. Essa geração é composta por jovens que viveram no país de chegada, que cresceram utilizando outra língua, vivendo outra cultura e com outros comportamentos. Por isso, elas não possuem um sentimento de pertencimento com o país latino americano em que nasceram, não consideram esse país como o "seu lugar" e desejam permanecer na Suécia.

O deslocamento sofrido ainda na infância e no início da adolescência faz com que as personagens da segunda geração dos romances assumam um sentimento de desenraizamento com a terra natal. Se para a primeira geração estar no país de chegada era apenas " [...] una suerte de "mientras tanto", una vida provisoria, untiempo que iba a terminar" (SILVA SCHULTZE, 2006, p. 18); para a segunda, esse era o país que conheciam das conversas familiares, mas com o qual não criaram laços ou raízes: "Sergio no recordava Chile, así como Andrea no recordaba Uruguay" (SILVA SCHULTZE, 2006, p. 18).

Nos romances, as personagens Gabriela e Andrea, pertencentes à segunda geração do exílio, não possuem raízes com a terra natal e tampouco sentem a Suécia como o seu país. Não criam raízes nem com o país de origem e nem com o de chegada. O país europeu é apenas um lugar onde podem "estar" no momento presente, como poderiam estar em qualquer outra parte do mundo, tanto que Gabriela vive algum tempo com o namorado no Sudão. Nesse ponto, elas se diferem de seus pais, pertencentes à primeira geração, que 
consideram apenas o país de origem como seu local de pertencimento e formador de sua identidade nacional. As duas jovens da segunda geração cresceram em universos culturais diferentes dos países de origem e suas vidas se construíram na passagem, na travessia. Por tal motivo, necessitaram "negociar" entre as culturas, em um processo constante de adaptação ao "novo" criado pelo processo de desterritorialização e reterritorialização. Elas são de uma geração que viveu no entre-lugar cultural, que não rejeitou e tampouco assimilou a cultura do país de chegada, mas as mesclou, criando uma cultura heterogênea e, por conseguinte, uma identidade híbrida e plural. Nos romances, a vida fora da terra natal e os constantes deslocamentos realizados por Gabriela e Andrea contribuíram para o desenraizamento e a construção de uma subjetividade nômade, tal qual a definida por Braidot (2002, p. 10):

Em meu último livro fiz a distinção entre subjetividade nômade e duas outras figurações com as quais é frequentemente - de modo desfavorável comparada: primeiro o migrante, depois o exilado. $\mathrm{O}$ itinerário clássico do migrante é composto por lugares fixos: da "casa" para os países "anfitriões", em uma série de deslocamentos consecutivos. Argumentei que o migrante como figura das duras condições econômicas - tende a se apoiar nos valores "natais", enquanto tenta se adaptar àqueles do ambiente anfitrião (um corte congelado de história). [...] O nômade por outro lado se posiciona pela renúncia e desconstrução de qualquer senso de identidade fixa. O nômade é semelhante ao que Focault chamou de contramemória, é uma forma de resistir à assimilação ou homologação dentro de formas dominantes de representar a si próprio. [...] $\mathrm{O}$ estilo nômade tem a ver com transições e passagens, sem destinos pré-determinados ou terras natais perdidas.

Sob essa perspectiva, as protagonistas principais dos dois romances vivem a desterritorialização não como privação, como a primeira geração do exílio, mas como uma maneira de ser e agir. A personagem Andrea,desde o início da narrativa, afirma para si uma subjetividade nômade, desprovida de referenciais fixos: "Yo me voy a quedar aquí [Suecia], me voy a ir a vivir con Sergio y voy a dedicar el resto de mi vida a la música, aqui o en cualquier otra parte del planeta" (SILVA SCHULTZE, 2006, p. 10). Essa constatação de ser um sujeito nômade não acontece de imediato com a personagem Gabriela, do romance de Dresdner. Somente após vários deslocamentos entre o Chile, o Sudão e a Suécia, ela se percebe como sujeito nômade, sem pertencimento fixo. Os 
constantes deslocamentos contribuem para que, pouco a pouco, ela se transforme de sujeito migrante para sujeito nômade: “¿En qué estoy? Aún atorada en la eterna duda del origen, las raíces, el destierro, etc. Dudas más bien añejas, sin nada nuevo, ni para mí ni para nadie que haya dejado alguna vez su país para irse a otro" (DRESDNER, 2012, p. 233).

A descoberta de ser um sujeito nômade acontece para Gabriela apenas no final da narrativa. Ao voltar sozinha para o Chile, anos após a volta da mãe, a personagem decide ficar no país na tentativa de reencontrar o Chile que fazia parte de sua memória coletiva. Após alguns anos de desexílio, o sentimento de estranhamento, de não pertencimento com o país natal retorna e ela deseja partir, e voltar para a Suécia. O sentimento de estranhamento com o país de origem é tão forte quanto o que sentiu ao chegar exilada à Suécia. No desexílio experimenta o sentimento de perda do país que deixou para trás, a Suécia. Gabriela começa a sentir-se estrangeira em seu próprio país:

Y sentí urgencia en cambiar. No tenía claro especificamente qué, pero si la urgencia. La sentía a diario. Y a diario recordaba Uppsala [...] He llegado a conclusión que yo soy el problema. La desadaptada [...] Desadaptada, extraña, extranjera. (DRESDNER, 2012, p. 210-1)

O estranhamento está presente em cada cidade pela qual passa Gabriela. Elase sente estranha em todas elas e não cria raízes em nenhuma. Após um tempo em uma cidade, sente o desejo de mudança e se coloca novamente em trânsito, sabendo qual será o percurso a fazer: voltar às cidades de sua memória - Santiago de Chile, Uppsala, na Suécia-, retomando um itinerário que, por quantas vezes percorrido, será sempre diferente. No Chile, a personagem conscientiza-se de que a inadequação ao lugar em que se encontra está em si mesma e não no espaço geográfico e mais uma vez se desloca. Desta vez, faz novamente o trajeto que percorreu no exílio, do Chile para a Suécia, na tentativa de reencontra-se.

Se Gabriela precisa voltar ao seu país de origem para constatar que não pertence a ele, pois construiu ao longo dos anos uma subjetividade nômade, o mesmo não ocorre com a personagem Andrea. Desde o início da narrativa, são os laços afetivos que a unem à família, principalmente os construídos coma avó, e não o local onde a família se encontra. 
Viajar para o Uruguai não é reencontrar suas raízes e tampouco sua terra natal, mas reencontrar o núcleo familiar que há dois anos havia partido da Suécia para o Uruguai: "Andrea los extrañaba [la familia] y cualquier lugar del mundo le hubiera venido bien" (SILVA SCHULTZE, 2006, p. 17).

A diferença entre o sentimento de desenraizamento das duas personagens com o país natal pode ser explicada, segundo Espina Bocic e Sanhueza Comte (2014, p. 103), pela idade com que saíram do país de origem. Para os autores, quanto mais jovens os filhos dos exilados deixam o país natal, mais esse país se transforma em uma imagem irreal e utópica e mais o pertencimento com o país de chegada é reforçado. No romance, a idade das personagens ao saírem do país corrobora tais constatações. Andrea saiu do Uruguai com apenas três anos e, por isso, não cria laços com o país natal. Seus laços são afetivos e com a família que vive ali. Por tal motivo, não se vê vivendo no Uruguai, cuja cultura e comportamentos são desconhecidos e às vezes, incompreensíveis para ela.

Já Gabriela saiu com treze anos. Nessa idade, algumas raízes com o lugar de origem são criadas. Motivo pelo qual, ela retorna ao Chile e tenta viver parte de sua vida ali, mas não consegue fixar-se. Percebemos que em maior ou menor grau (explicado pela idade com que deixam a terra natal), as personagens constroem um sentimento de desenraizamento que lhes permite manter filiações simultâneas a culturas diversas, mostrando que seus percursos são mais importantes que suas raízes.

\section{A feminização da diáspora}

Os dois romances concedem o protagonismo às personagens Gabriela e Andrea e às personagens femininas secundárias. Os deslocamentos espaciais e culturais das protagonistas e a consequente construção de uma subjetividade nômade evidenciam nos romances uma das características mais significativas em termos dos deslocamentos atuais: a maior participação feminina nos deslocamentos nacionais e internacionais. Antes, as mulheres somente abandonavam seus países se acompanhadas de suas famílias e, principalmente, dos seus maridos. Atualmente, prevalece o caráter autônomo dessa mobilidade feminina: as mulheres deixam sozinhas seus países para trabalhar, viajar ou morar no exterior. Há um novo tipo de deslocamento motivado também por fatores subjetivos. 


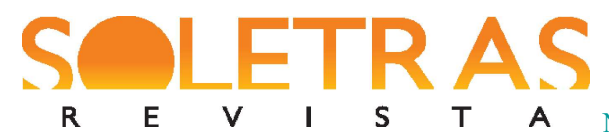

N. 38 - 2019.2 - ANA CRISTINA DOS SANTOS

Nos romances, as duas personagens principais (e também as outras secundárias) se deslocam, por motivos diferentes, e o fazem sempre sozinhas. São elas que decidem para onde vão e em que momento. Quando se deslocam acompanhadas, como no caso da mãe de Andrea que parte para o Uruguai com o marido e o filho, a decisão é tomada por ela. Desse modo, os romances corroboram para propagar o conceito que a teórica Avtar Brah denomina de feminização da diáspora ${ }^{8}$, ressaltando, assim, o caráter gendrado dos deslocamentos contemporâneos. Essa característica também perpassa na ficcionalização dos deslocamentos atuais: nos romances escritos por mulheres (como no caso dos dois analisados), as personagens femininas passam a ser protagonistas das narrativas que tratam do desenraizamento e do viver nos entre-lugares provenientes desses espaços de movência.

Ao tematizar o exílio, o desexílio e a desterritorialização da segunda geração de exilados, os romances Pasajeros en tránsito e Apenas diez se deslocam do espaço privado (inerente ao trânsito feminino) para o público. Ao mesmo tempo, expandem o espaço das narrativas para além das fronteiras nacionais das personagens. No romance Pasajeros en tránsito, o deslocamento de Gabriela ao Sudão lhe permite refletir sobre as tradições culturais do país com relação às mulheres e dialogar com elas. Ao reunir diversidade cultural e gênero, a narrativa amplia a visão de Gabriela e a faz compreender um pouco mais sobre si mesma. É nesse momento que decide retornar ao Chile, sua pátria natal, e enxergar-se como chilena e latino-americana. A aceitação também de sua identidade chilena mostra que os conflitos identitários provenientes dos deslocamentos e dos encontros interculturais modificam o sujeito feminino.

Nos romances, as autoras exploram a literatura como uma prática política e social que visibiliza a mulher como parte constitutiva da sociedade cosmopolita contemporânea. As personagens desterritorializadas circulam pelas cidades cosmopolitas, em espaços públicos e em atividades fora do lar. Elas estabelecem uma nova relação com os espaços pelos quais circulam, na qual não há o privilégio de um sobre o outro, mas a interação entre eles. Essas personagens habitam os entre-lugares provenientes dos espaços de movência, em um processo constante de desenraizamento. Nesse espaço "entre" em que vivem, não mais se incorporam à nova cultura e, tampouco, abandonam a de origem, mas criam uma terceira, nos interstícios

\footnotetext{
${ }^{8}$ Para a crítica feminista Avtar Brah (2011), a participação da mulher na sociedade contemporânea, seu papel como sujeito atuante e sua participação nos deslocamentos nacionais e transnacionais é um dos elementos diferenciadores dos deslocamentos anteriores para os de agora, o que a teórica denomina como feminização da diáspora.
} 


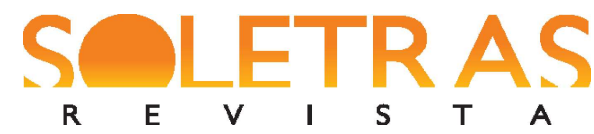

N. 38 - 2019.2 - ANA CRISTINA DOS SANTOS

das duas. Nesse espaço transitório, aprendem a traduzir e a negociar no entre-dois e a operar em um código plural, conscientes da hibridez cultural e das heterogeneidades presentes em seu ser.

Nesse espaço, a identidade feminina também está em constante devir: constrói-se nos diversos encontros e desencontros culturais pelos quais passam Andrea e Gabriela, pertencentes à segunda geração de exilados retratada nos romances. A identidade das personagens corresponde à construída a partir de um contínuo processo de readequação e readaptação às diversas culturas pelas quais transitam. Suas subjetividades não se constroem em torno de referências culturais únicas, são compostas de forma tão plural quanto os espaços pelos quais se deslocam. Consequentemente, a subjetividade dessas personagens está em constante estado de renegociação, pois são identidades culturais "em transição... que retiram seus recursos, ao mesmo tempo; de diferentes tradições culturais; e que são o produto desses complicados cruzamentos e misturas culturais que são cada vez mais comuns num mundo globalizado" (HALL, 2005, p. 88).

\section{Considerações finais}

Ao dar protagonismo ao deslocamento das personagens femininas, verificamos que os romances Passajeros en trânsito e Apenas diez enfatizam o caráter gendrado da mobilidade espacial contemporânea. Por meio das experiências dos deslocamentos de Gabriela e Andrea e de seu núcleo familiar, os romances discutem os processos de exílio e desexílio, ressaltando que o exílio origina dois grupos de sujeitos. O primeiro, representado pela mãe e pelo irmão de Gabriela e pela mãe e pelo padrasto de Andrea corresponde àqueles que, já adultos, saíram do país e mantiveram o apego à identidade nacional e à afiliação a uma raiz única e desejam veementemente voltar ao país de origem, mesmo conscientes de que o país que encontrarão não corresponde ao "guardado" na memória. Esses sujeitos fazem parte da primeira geração do exílio e, nos romances, são caracterizados principalmente pelos progenitores ou pelos irmãos adultos das personagens principais.

O segundo grupo é composto pelos jovens que, como Gabriela e Andrea (e em Pasajeros en tránsito pelos outros jovens latino-americanos do grupo de amizade de Gabriela), saíram de seus países de origem, levados pelos pais exilados, na infância ou no 
início da adolescência. Nesse deslocamento, perderam os referenciais de nação e, consequentemente, o sentimento de nacionalidade e de afiliação a um único território. Esse grupo estabelece uma nova relação com o país de chegada, que não é de perda e tampouco de assimilação, mas de negociação e tradução entre a cultura do país de origem e a do país de chegada. Esses jovens constituem a segunda geração do exílio e, tais quais as protagonistas dos romances possuem como característica principal o desapego às raízes e a construção de uma subjetividade nômade: sua "casa" pode ser em qualquer lugar.

Nos romances, Gabriela e Andrea se conscientizam de que o sentimento de pertencimento único é ilusório, pois o "lar" não é um lugar fixo, mas aquele onde desejam estar. Para elas, como destacam os romances analisados, o desenraizamento não se relaciona apenas com a geografia, com o trânsito de um lugar para o outro, com o exterior, mas também com o interior, consequência do estranhamento que sentem quando começam a criar raízes com um espaço geográfico. Seu "lugar" pode ser em qualquer um onde elas desejam estar. Assim, por meio das duas personagens femininas autônomas que circulam pelos espaços das cidades urbanas, os romances enfatizam os deslocamentos da segunda geração do exílio, assinalando que os deslocamentos espaciais conduzem aos deslocamentos internos e, por conseguinte, à construção de uma subjetividade feminina desenraizada; logo, nômade e plural.

\section{Referências}

BENEDETTI, Mario. El 'desexilio'. Periódico El país. Madrid, 18 de abril de 1983. Disponível em: <https://elpais.com/diario/1983/04/18/opinion/419464807_850215.html>. Acesso em 18 jul. 2017.

BRAH, Avtar. Cartografias de la diáspora. Identidades en cuestión. Trad de Sergio Ojeda. Madrid: Traficantes de sueños, 2011.

BRAIDOTTI, Rosi. Diferença, diversidade e subjetividades nômades. Labrys. Estudos feministas. Brasília/UNB, num.1-2, junho-dezembro 2002. Disponível em: $<$ http://www.unb.br/ih/his/gefem >. Acesso em: 25 mar. 2013.

DRESDNER, Rossana. Pasajeros en tránsito. Santiago de Chile: LOM Ediciones, 2012.

ESPINA BOCIC, Nicolás; SANHUEZA COMTE, Aline. La construcción de identidad em hijos/as de exiliados/as políticos/as chilenos/as. Revista de Psicología. Universidad Viña del Mar, 2014, Vol. 4, $\mathrm{n}^{\mathrm{o}}$ 8, p. 72-111. Disponível em: <http://sitios.uvm.cl/revistapsicologia/revistadetalle.php/8/48/contenido/la-construccion-de-identidad-en-hijosas-de-exiliadosas-politicosaschilenosas>. Acesso em: 02 mar. 2017. 
GARCÍA CANCLINI, Nestor. Culturas híbridas. Trad. de Ana Regina Lessa et al. 4 ed, 4 reimp. São Paulo: Edusp, 2008.

HALL, Stuart. A identidade cultural na pós-modernidade. Trad. de Tomaz Tadeu da Silva e Guacira Lopes Louro. 10 ed. Rio de Janeiro: DP\&A, 2005.

IANNI, Octavio. A metáfora da viagem. In: Enigmas da modernidade-mundo. 3 ed. Rio de Janeiro: Civilização Brasileira, 2003. p. 11-31.

NORANDI, Mariana. El no retorno de la segunda generación del exilio uruguayo en España: habitando un espacio sin construir. Historia, Voces y Memoria. Revista del Programa de Historia ORAL, Universidad de Buenos Aires, n. 8, 2015, p. 51-64. Disponível em: $<$ http://revistascientificas.filo.uba.ar/index.php/HVM/article/view/1893/1774>. Acesso em: 15 nov. 2016.

RODRÍGUEZ MONEGAL, Emir. Literatura y exilio. Revista Vuelta. México, vol. 6, n.63, febrero 1982, p. 45-7. Disponível em: <http://literaturarioplatense.blogspot.com.br/ 2010/01/literatura-y-exilio-emir-rodriguez.html>. Acesso em: 24 mai. 2017.

SAID, Edward. Reflexões sobre o exílio. In: . Reflexões sobre o exílio e outros ensaios. Trad. de Pedro Maia Soares. Rio de Janeiro: Companhia das Letras, 2003. p. 46-60.

SILVA SCHULTZE, Marisa. Apenas diez. Montevideo: Ediciones Santillana, 2006.

\title{
Displaced female subjects or the new experiences of non-belonging
}

\begin{abstract}
This paper discusses the new relations with space resulting from the experiences of displacements and the consequences for the female characters who are components of what is called the second generation exile - children of exiled parents from Latin American dictatorships. This paper also aims to verify how the loss of spatial referents modifies these displaced female subjects. In order to do so, the focus of the analysis will be the leading female characters of the novels Apenas diez (2006), by the Uruguayan writer Marisa Silva Schultze, and Pasajeros en tránsito (2013), by the Chilean writer Rossana Dresdner. It is observed that the novels problematize the continuous "being in transit" of the characters and their cultural ambiguity that allows them, based on the displacement experience, the construction of a nomadic subjectivity that produces hybrid and translated subjects. For the proposed analysis, I will use the texts of Norandi (2015) and Espina Bocic; Sanhueza Comte (2014) on the second generation of exile; Brah (2011) and García Canclini (2009) for the concepts of space and displacement; Said (2003) for the issues of exile; Benedetti (1983) for the concept of desexile; and Hall (2005) and Braidotti (2002) for the questions of identity in the contemporaneity.
\end{abstract}

Keywords: Displacement. Women writers. Exile. Nomadic subjectivity.

Recebido em: 07 de julho de 2019.

Aceito em: 07 de julho de 2019. 